\title{
Kinetic Modeling of the Decomposition of Carbon Tetrachloride in Thermal Plasma
}

\author{
Tamás Kovács, ${ }^{1}$ Tamás Turányi, ${ }^{1}$ Katalin Föglein,,${ }^{2,3}$ \\ and János Szépvölgyi ${ }^{2}$
}

Received October 15, 2003; revised July 1, 2004

\begin{abstract}
Decomposition of carbon tetrachloride in a RF thermal plasma reactor was investigated in argon atmosphere. The net conversion of $\mathrm{CCl}_{4}$ and the main products of its decomposition were determined from the mass spectrometric analysis of outlet gases. Flow and temperature profiles in the reactor were calculated and concentration profiles of the species along the axis of the reactor were estimated using a newly developed chemical kinetic mechanism, containing 12 species and 34 reaction steps. The simulations indicated that all carbon tetrachloride decomposed within a few microseconds. However, $\mathrm{CCl}_{4}$ was partly recombined from its decomposition products. The calculations predicted $70 \%$ net conversion of $\mathrm{CCl}_{4}$, which was close to the experimentally determined value of $60 \%$. A thermodynamic equilibrium model also simulated the decomposition. Results of the kinetic and thermodynamic simulations agreed well above $2000 \mathrm{~K}$. However, below $2000 \mathrm{~K}$ the thermodynamic equilibrium model gave wrong predictions. Therefore, application of detailed kinetic mechanisms is recommended for modeling $\mathrm{CCl}_{4}$ decomposition under thermal plasma conditions.
\end{abstract}

KEY WORDS: Carbon tetrachloride; thermal plasma; decomposition.

\section{INTRODUCTION}

In the 1960s, halogenated hydrocarbons, such as chloroform and carbon tetrachloride, were frequently used solvents in the chemical industry. Freons were also applied in many industrial and other fields because of their advantageous properties like being non-toxic, cheap, and easy to produce. In the last decades, it became clear that these materials are directly responsible for the global warming and the depletion of stratospheric ozone. Therefore, international treaties have banned their applications. However, large quantities are still being stored waiting for a

${ }^{1}$ Department of Physical Chemistry, Eötvös University (ELTE), 1518 Budapest, P.O. Box 32, Hungary.

${ }^{2}$ Research Laboratory of Materials and Environmental Chemistry, Chemical Research Center, Hungarian Academy of Sciences, 1525 Budapest, P.O. Box 17, Hungary.

${ }^{3}$ To whom correspondence should be addressed. E-mail: fogleink@chemres.hu 
safe decomposition technology. Traditional technologies like incineration or catalytic decomposition are not efficient enough on one hand and sometimes they generate products that are even more dangerous for the environment and the human health on the other.

Decomposition under thermal plasma conditions represents a safe and environmental friendly technology for processing halogenated hydrocarbons. In the last few years, extensive experimental work has been done and many papers have been published that show the research interest in this technology. However, only few papers are available on the modeling of the decomposition of halogenated hydrocarbons in thermal plasmas.

\section{DESCRIPTION OF THE EXPERIMENTAL CONDITIONS AND THE KINETIC MODEL}

Föglein et al. ${ }^{(1)}$ investigated the decomposition of carbon tetrachloride in an inductively coupled, RF thermal plasma reactor. This reactor had a length of $150 \mathrm{~mm}$ and a diameter of $26 \mathrm{~mm}$ and operating with a plate power of $2.1 \mathrm{~kW}$ Argon was used as plasma gas $\left(81 \cdot \min ^{-1}\right.$ (STP)) and sheath gas (21 $1 \cdot \mathrm{min}^{-1}$ (STP)), respectively. Atmospheric pressure was maintained in the whole system. The gas mixture to be decomposed consisted of $0.93 \mathrm{~m} \% \mathrm{CCl}_{4}$ and $99.07 \mathrm{~m} \%$ Ar. Conversion (i.e. extent of decomposition) of $\mathrm{CCl}_{4}$ and the main decomposition products were determined from the GC-MS analysis of outlet gases. At experimental conditions as above, a $\mathrm{CCl}_{4}$ conversion of $60 \%$ was achieved and the main $\mathrm{C}$-atom containing compounds in the outlet gas were $\mathrm{C}_{2} \mathrm{Cl}_{4}(68 \%), \mathrm{C}_{2} \mathrm{Cl}_{6}$ $(14 \%)$, and $\mathrm{CCl}_{4}(18 \%)$.

Using the 2D plasma model of Proulx and Bilodeau ${ }^{(2)}$ that was developed for RF thermal plasmas, we have calculated the temperature and the velocity profiles within the reactor. Temperature pattern for conditions used in this work is shown in Fig. 1. Using the temperature and flow velocity profiles, the approximate temperature of the gas phase as a function of time was determined along the axis of the reactor (Fig. 2). The linear gas velocity in the centerline of the reactor varied from 30 to $60 \mathrm{~cm} \cdot \mathrm{s}^{-1}$. Thus, diffusion could be neglected and spatially homogeneous plug-flow simulations were carried out with the SENKIN code ${ }^{(3)}$ of the CHEMKIN-II gas kinetics simulation program package. ${ }^{(4)}$ Systems with inhomogeneous concentration, temperature and flow fields can be modeled based on either the Euler or the Lagrange approach. In the former, the system is covered with a grid and the concentration changes in all grid points are simulated simultaneously. The Euler approach usually requires considerably computer time. According to the Lagrange approach, concentration-time changes are calculated in air parcels, and 


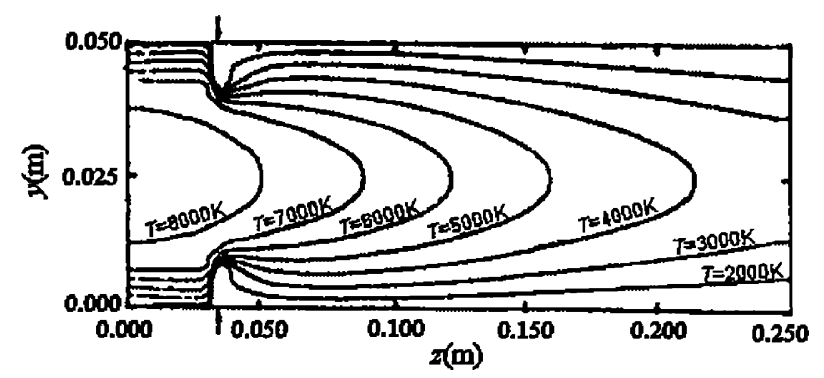

Fig. 1. Temperature profiles calculated by $2 \mathrm{D}$ plasma model; Feeding of $\mathrm{CCl}_{4}$ into the tail flame region is indicated by arrows; Plasma gas: Ar $81 \cdot \mathrm{min}^{-1}$ (STP), sheath gas: Ar $211 \cdot \mathrm{min}^{-1}(\mathrm{STP})$, plate power: $2.1 \mathrm{~kW}$.

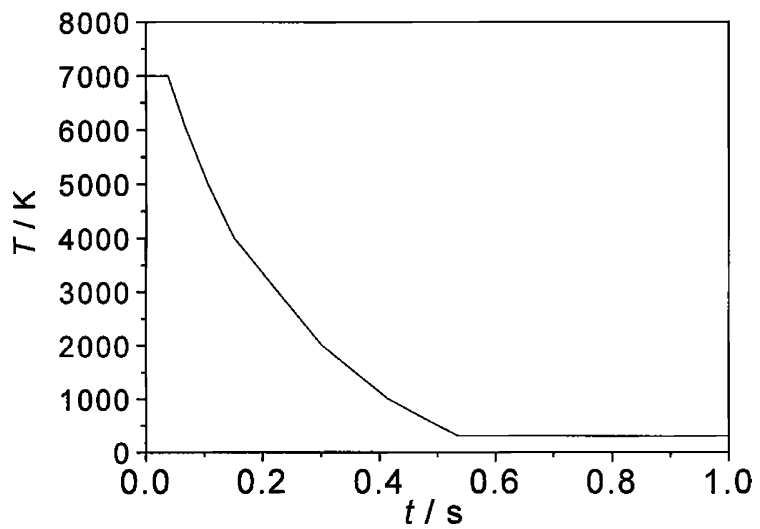

Fig. 2. The estimated temperature-time profile along the axis of the reactor.

the temperature-time history of the parcels is determined from the temperature and flow fields. The Lagrange approach can handle systems with diffusion. However, if diffusion is neglected, the concentration changes in each air parcel can be calculated separately. The concentration changes are calculated using a plug-flow model, while the modeled air parcel actually is moving according to inhomogeneous temperature and flow fields.

A detailed reaction mechanism was constructed for describing the decomposition of $\mathrm{CCl}_{4}$ in argon gas at high temperatures. The reaction mechanism (Table I) contains 12 species and 34 reactions. The thermodynamic data for the species and the kinetic parameters of reactions were obtained from the Burcat's Thermodynamic Database ${ }^{(5)}$ and the NIST Chemical Kinetics Database, ${ }^{(6)}$ respectively. Arrhenius parameters were not found for reaction steps 3 and 7. Particular Arrhenius parameters were 
Table I. The Detailed Mechanism for the Decomposition of $\mathrm{CCl}_{4}$ in Argon Atmosphere

\begin{tabular}{|c|c|c|c|c|}
\hline Reactions & $\mathrm{A} / \mathrm{s}^{-1}$ & $n$ & $C / \mathrm{KJ} \mathrm{mol}^{-1}$ & References \\
\hline $\mathrm{CCl}_{4}+\mathrm{Ar} \rightarrow \mathrm{CCl}_{3}+\mathrm{Cl}+\mathrm{Ar}$ & $8.33 \times 10^{54}$ & -10.6 & 313 & (12) \\
\hline $\mathrm{CCl}_{3}+\mathrm{Cl}+\mathrm{Ar} \rightarrow \mathrm{CCl}_{4}+\mathrm{Ar}$ & $1.71 \times 10^{47}$ & -9.1 & 19.8 & a \\
\hline $\mathrm{CCl}_{3}+\mathrm{Ar} \rightarrow \mathrm{CCl}_{2}+\mathrm{Cl}+\mathrm{Ar}$ & $1.57 \times 10^{49}$ & -9.0 & 386 & $(13), b$ \\
\hline $\mathrm{CCl}_{2}+\mathrm{Cl}+\mathrm{Ar} \rightarrow \mathrm{CCl}_{3}+\mathrm{Ar}$ & $8.63 \times 10^{43}$ & -8.1 & 90.0 & a \\
\hline $\mathrm{CCl}_{2}+\mathrm{Ar} \rightarrow \mathrm{CCl}+\mathrm{Cl}+\mathrm{Ar}$ & $4.40 \times 10^{15}$ & 0.0 & 283 & (14) \\
\hline $\mathrm{CCl}+\mathrm{Cl}+\mathrm{Ar} \rightarrow \mathrm{CCl}_{2}+\mathrm{Ar}$ & $1.91 \times 10^{10}$ & 1.2 & -99.6 & a \\
\hline $\mathrm{CCl}+\mathrm{Ar} \rightarrow \mathrm{C}+\mathrm{Cl}+\mathrm{Ar}$ & $4.32 \times 10^{15}$ & 0.0 & 290 & $(15), b$ \\
\hline $\mathrm{C}+\mathrm{Cl}+\mathrm{Ar} \rightarrow \mathrm{CCl}+\mathrm{Ar}$ & $2.30 \times 10^{13}$ & 0.5 & -56.3 & a \\
\hline $\mathrm{CCl}_{2}+\mathrm{C} \rightarrow 2 \mathrm{CCl}$ & $1.62 \times 10^{12}$ & 0.0 & 196 & (14) \\
\hline $2 \mathrm{CCl} \rightarrow \mathrm{CCl}_{2}+\mathrm{C}$ & $1.34 \times 10^{9}$ & 0.7 & 153 & a \\
\hline $\mathrm{CCl}_{4}+\mathrm{Cl} \rightarrow \mathrm{CCl}_{3}+2 \mathrm{Cl}$ & $5.75 \times 10^{13}$ & 0.0 & 65.8 & (16) \\
\hline $\mathrm{CCl}_{3}+2 \mathrm{Cl} \rightarrow \mathrm{CCl}_{4}+\mathrm{Cl}$ & $1.18 \times 10^{6}$ & 1.5 & -227 & a \\
\hline $\mathrm{CCl}_{4}+\mathrm{C} \rightarrow \mathrm{CCl}_{3}+\mathrm{CCl}$ & $9.04 \times 10^{12}$ & 0.0 & 0.0 & (17) \\
\hline $\mathrm{CCl}_{3}+\mathrm{CCl} \rightarrow \mathrm{CCl}_{4}+\mathrm{C}$ & $3.54 \times 10^{7}$ & 0.9 & 46.6 & a \\
\hline $2 \mathrm{CCl}_{3} \rightarrow \mathrm{C}_{2} \mathrm{Cl}_{6}$ & $4.55 \times 10^{12}$ & -1.6 & 1.5 & (18) \\
\hline $\mathrm{C}_{2} \mathrm{Cl}_{6} \rightarrow 2 \mathrm{CCl}_{3}$ & $3.83 \times 10^{26}$ & -4.5 & 288 & a \\
\hline $\mathrm{C}_{2} \mathrm{Cl}_{6}+\mathrm{CCl}_{3} \rightarrow \mathrm{CCl}_{4}+\mathrm{C}_{2} \mathrm{Cl}_{5}$ & $7.94 \times 10^{11}$ & 0.0 & 59.9 & (19) \\
\hline $\mathrm{C}_{2} \mathrm{Cl}_{5}+\mathrm{CCl}_{4} \rightarrow \mathrm{CCl}_{3}+\mathrm{C}_{2} \mathrm{Cl}_{6}$ & $2.95 \times 10^{8}$ & 0.8 & 39.5 & a \\
\hline $\mathrm{C}_{2} \mathrm{Cl}_{5}+\mathrm{Cl}_{2} \rightarrow \mathrm{C}_{2} \mathrm{Cl}_{6}+\mathrm{Cl}$ & $2.04 \times 10^{11}$ & 0.0 & 9.9 & (19) \\
\hline $\mathrm{C}_{2} \mathrm{Cl}_{6}+\mathrm{Cl} \rightarrow \mathrm{C}_{2} \mathrm{Cl}_{5}+\mathrm{Cl}_{2}$ & $3.51 \times 10^{17}$ & -1.1 & 64.7 & a \\
\hline $\mathrm{C}_{2} \mathrm{l}_{5} \rightarrow \mathrm{C}_{2} \mathrm{Cl}_{4}+\mathrm{Cl}$ & $1.12 \times 10^{16}$ & 0.0 & 62.4 & (18) \\
\hline $\mathrm{C}_{2} \mathrm{Cl}_{4}+\mathrm{Cl} \rightarrow \mathrm{C}_{2} \mathrm{Cl}_{5}$ & $3.82 \times 10^{13}$ & 0.7 & -0.61 & a \\
\hline $\mathrm{C}_{2} \mathrm{l}_{5}+\mathrm{Cl} \rightarrow \mathrm{C}_{2} \mathrm{Cl}_{4}+\mathrm{Cl}_{2}$ & $2.45 \times 10^{11}$ & 0.0 & 0.00 & (18) \\
\hline $\mathrm{C}_{2} \mathrm{Cl}_{4}+\mathrm{Cl}_{2} \rightarrow \mathrm{C}_{2} \mathrm{Cl}_{5}+\mathrm{Cl}$ & $6.37 \times 10^{15}$ & -0.4 & 195 & a \\
\hline $2 \mathrm{Cl}+\mathrm{Ar} \rightarrow \mathrm{Cl}_{2}+\mathrm{Ar}$ & $2.00 \times 10^{15}$ & 0.0 & 0.00 & (20) \\
\hline $\mathrm{Cl}_{2}+\mathrm{Ar} \rightarrow 2 \mathrm{Cl}+\mathrm{Ar}$ & $1.52 \times 10^{20}$ & -1.1 & 258 & a \\
\hline $2 \mathrm{CCl}+\mathrm{Ar} \rightarrow \mathrm{C}_{2} \mathrm{Cl}_{2}+\mathrm{Ar}$ & $5.40 \times 10^{14}$ & 0.0 & 63.5 & (14) \\
\hline $\mathrm{C}_{2} \mathrm{Cl}_{2}+\mathrm{Ar} \rightarrow 2 \mathrm{CCl}+\mathrm{Ar}$ & $4.56 \times 10^{24}$ & -1.9 & 858 & a \\
\hline $2 \mathrm{CCl}_{2}+\mathrm{Ar} \rightarrow \mathrm{C}_{2} \mathrm{Cl}_{4}+\mathrm{Ar}$ & $5.70 \times 10^{15}$ & 0.0 & 24.9 & (14) \\
\hline $\mathrm{C}_{2} \mathrm{Cl}_{4}+\mathrm{Ar} \rightarrow 2 \mathrm{CCl}_{2}+\mathrm{Ar}$ & $4.14 \times 10^{26}$ & -1.9 & 527 & a \\
\hline $\mathrm{C}_{2} \mathrm{Cl}_{2}+\mathrm{Cl}+\mathrm{Ar} \rightarrow \mathrm{C}_{2} \mathrm{Cl}_{3}+\mathrm{Ar}$ & $3.55 \times 10^{7}$ & 0.9 & 46.6 & (14), b \\
\hline $\mathrm{C}_{2} \mathrm{Cl}_{3}+\mathrm{Ar} \rightarrow \mathrm{C}_{2} \mathrm{Cl}_{2}+\mathrm{Cl}+\mathrm{Ar}$ & $6.59 \times 10^{11}$ & -0.1 & 192 & $\mathrm{a}$ \\
\hline $\mathrm{C}_{2} \mathrm{Cl}_{3}+\mathrm{Cl} \rightarrow \mathrm{C}_{2} \mathrm{Cl}_{4}$ & $2.45 \times 10^{13}$ & 0.0 & 0.00 & $(18), b$ \\
\hline $\mathrm{C}_{2} \mathrm{Cl}_{4} \rightarrow \mathrm{C}_{2} \mathrm{Cl}_{3}+\mathrm{Cl}$ & $6.03 \times 10^{20}$ & -1.4 & 327 & a \\
\hline
\end{tabular}

${ }^{a}$ calculated from the rate parameters of the previous reaction and the thermodynamic data.

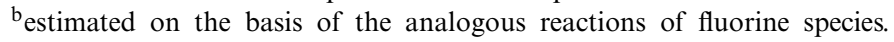

estimated from the rate parameters of analogous fluorine reactions. Temperature dependence of the rate parameters was described by the extended Arrhenius expression in the form of $k=A T^{n} \exp (-C / R T)$. For the evennumbered reaction steps, the rate parameters were calculated in accordance with the principle of detailed balancing using the kinetic parameters of the preceding ("forward") reaction steps and the equilibrium constant determined from the thermodynamic data using code MECHMOD. ${ }^{(7)}$ 
We would like to emphasize that the mechanism contains thermal reactions only, and no ionic species are present. It seems to be a good approximation, since at atmospheric pressure the ionization rate of the plasma and the concentration of electrons are low. In addition, the rate constants of the ionic reaction steps are much smaller than that of nonionic ones. Orlandini and Riedel ${ }^{(8)}$ studied the reactions of NO in thermal plasma at atmospheric pressure. They found that the ionic reactions under such conditions were slow as compared to the thermal, non-ionic reactions. Therefore, they also neglected the ionic reactions from the reaction mechanism.

\section{RESULTS OF SIMULATIONS}

Using the reaction mechanism as above along with the SENKIN code, ${ }^{(3)}$ the mass fraction profiles as a function of reaction time were calculated for all species. Figure $3 \mathrm{a}-\mathrm{e}$ show the profiles of mass fractions up to a reaction time of $0.1 \mathrm{~s}$. Carbon tetrachloride almost completely decomposed within $5 \times 10^{-5} \mathrm{~s}$ (Fig. 3a). However, after $0.03 \mathrm{~s} \mathrm{CCl}_{4}$ was recombined in a considerable extent from its fragments (Fig. 3d). If the temperature is above $3000 \mathrm{~K}$ (up to $2 \times 10^{-2} \mathrm{~s}$ ), the $\mathrm{C}$ and $\mathrm{Cl}$ radicals have almost stationary concentrations (Fig. 2b). According to our calculations, the stationary values are reached within $10^{-4} \mathrm{~s}$. The mass fraction of $\mathrm{CCl}_{2}$ radical has a maximum at $3 \times 10^{-2} \mathrm{~s}(2050 \mathrm{~K})$, and it decreases to a mass fraction of $5 \times 10^{-4}$ after 0.1 second.

Our calculations provided the simulated composition of the outlet gas, as well. The most important products in the outlet gas were $\mathrm{Cl}_{2}$, $\mathrm{CCl}_{4}, \mathrm{C}_{2} \mathrm{Cl}_{2}, \mathrm{C}_{2} \mathrm{Cl}_{4}$ and $\mathrm{C}_{2} \mathrm{Cl}_{6}$. A net $\mathrm{CCl}_{4}$ conversion of $70 \%$ was calculated, which was close to the experimentally determined value of $60 \%$.

Up to now, thermal decomposition of $\mathrm{CCl}_{4}$ was modeled by thermodynamic calculations only. ${ }^{(1)}$ In order to compare the kinetic modeling as above with the thermodynamic simulation, we also performed thermodynamic equilibrium calculations for the same reacting mixture, between $1000 \mathrm{~K}$ and $7000 \mathrm{~K}$. In Fig. 4a and b, the results of kinetic and thermodynamic equilibrium calculations are compared in terms of simulated mass fractions of $\mathrm{Cl}_{2}$ and $\mathrm{CCl}_{4}$. Above $2000 \mathrm{~K}$, the two methods gave actually similar results. However, below $2000 \mathrm{~K}$ results obtained by the two models are different. In this temperature region, the chemical reactions are slow and there is no time to reach the thermodynamic equilibrium. Therefore, application of chemical kinetic simulations based on detailed mechanisms is recommended for the modeling the decomposition of carbon tetrachloride in thermal plasmas. 

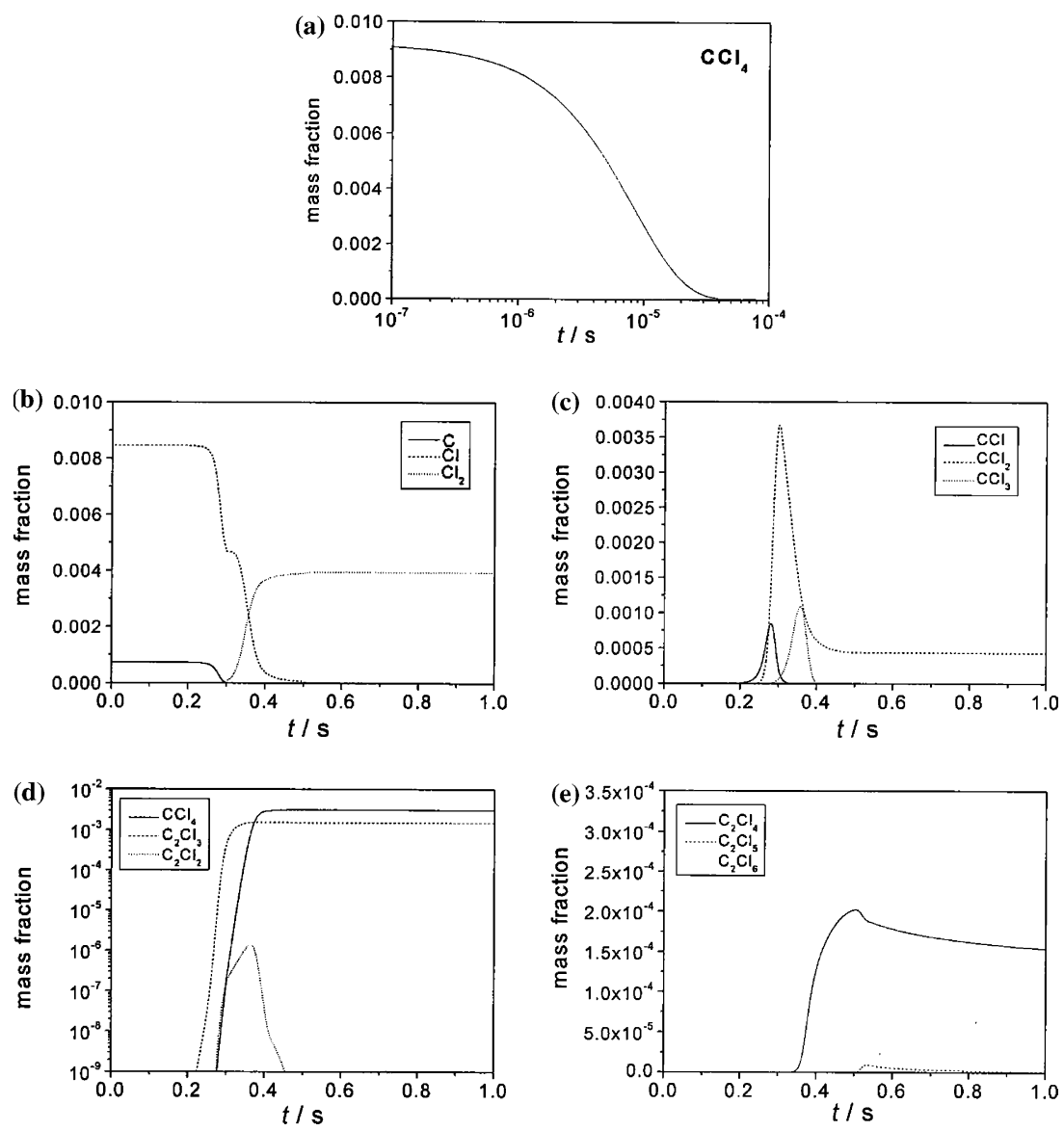

Fig 3a-e. Concentration profiles of the most important species.

Based on the shape of concentration profiles, reaction times corresponding to significant changes of the mass fractions of one or more species were selected (Table II). Kinetic analysis of $\mathrm{CCl}_{4}$ decomposition was carried out at these reaction times; net fluxes of $\mathrm{C}$ and $\mathrm{Cl}$ atoms were calculated by the KINALC ${ }^{(9)}$ code. The flux of an atom is the sum of the rates of all reaction steps that convert the given species to another, multiplied by the change of the number of atom investigated. Revel et al. ${ }^{(10)}$ have demonstrated usefulness of atom flux calculations in kinetic analysis. Changes in fluxes provide information on the fastest reaction steps at different reaction stages. 

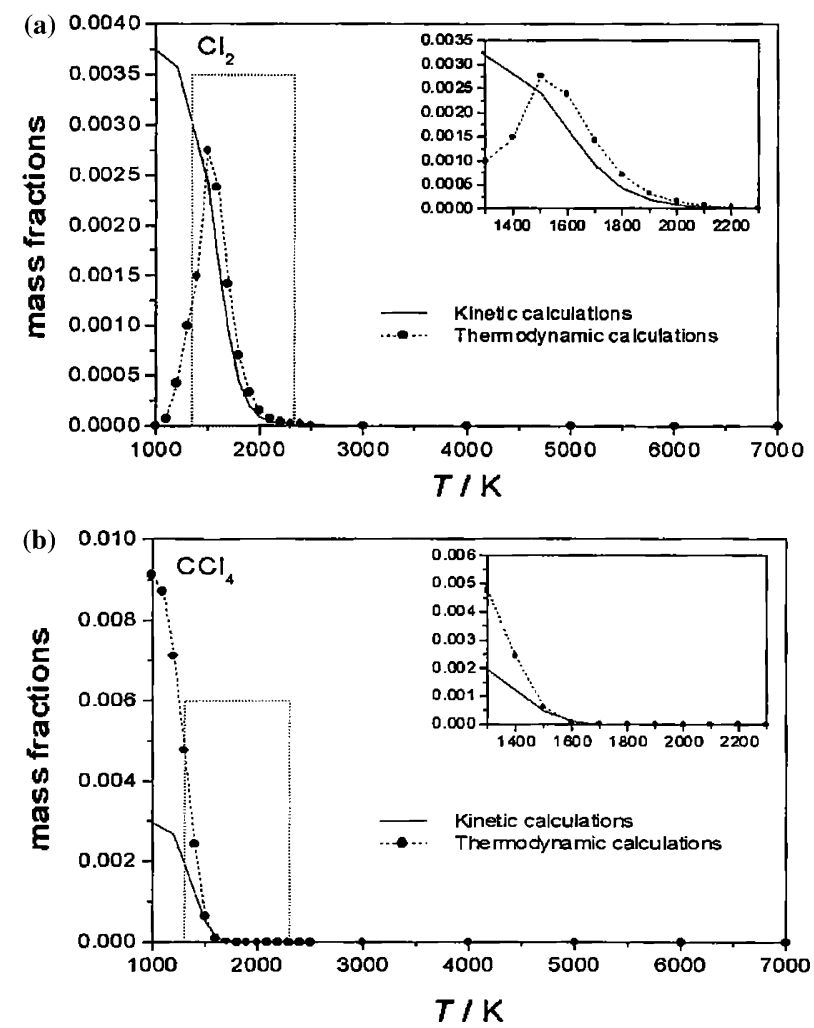

Fig. 4a-b. Results of kinetic and thermodynamic calculations for the mass fractions of $\mathrm{Cl}_{2}$ and $\mathrm{CCl}_{4}$, respectively.

In this work, the atom fluxes were determined at each reaction time listed in Table II. Figure 5 summarizes the fluxes of $\mathrm{C}$ and $\mathrm{Cl}$ atoms at five points of time corresponding to five different reaction temperatures. At a reaction time of $2.7 \times 10^{-2} \mathrm{~s}$ when the temperature is $7000 \mathrm{~K}$, the most important reaction step is the thermal decomposition of $\mathrm{CCl}_{4}$ (reaction No. 1). After $2.7 \times 10^{-2} \mathrm{~s}$, the temperature is much lower $(2420 \mathrm{~K})$, and the fast forward and backward reaction steps are in equilibrium. After $3.3 \times 10^{-2} \mathrm{~s}$ the temperature is $1748 \mathrm{~K}$, and it allows the formation of $\mathrm{C}_{2}$-species in low quantities. It is worth mentioning that other species such as $\mathrm{C}_{2} \mathrm{Cl}_{2}$ or $\mathrm{C}_{2} \mathrm{Cl}_{3}$ also play some role in the kinetics of the decomposition. However, the rates of their reactions are much lower than that of the other reaction steps showed in Fig. 5. Therefore, their corresponding fluxes were not plotted. There are no changes in the fluxes after $5 \times 10^{-2} \mathrm{~s}$, i.e. below $500 \mathrm{~K}$. 
Table II. Reaction Times Selected for Studying the Importance of Different the Reactions Steps

\begin{tabular}{lr}
\hline$t / \mathrm{S}$ & $T / \mathrm{K}$ \\
\hline $5.0 \times 10^{-7}$ & 7000 \\
$5.0 \times 10^{-5}$ & 7000 \\
$2.5 \times 10^{-1}$ & 2686 \\
$2.7 \times 10^{-1}$ & 2420 \\
$2.9 \times 10^{-1}$ & 2153 \\
$3.1 \times 10^{-1}$ & 1925 \\
$3.3 \times 10^{-1}$ & 1748 \\
$3.5 \times 10^{-1}$ & 1571 \\
$3.7 \times 10^{-1}$ & 1394 \\
$5.0 \times 10^{-1}$ & 500 \\
$5.2 \times 10^{-1}$ & 389 \\
$5.4 \times 10^{-1}$ & 300 \\
$6.0 \times 10^{-1}$ & 300 \\
\hline
\end{tabular}

KINALC $^{(9)}$ was also used to determine the most important decomposition and recombination steps at each reaction time. In general, a reaction can be regarded as an important one, if its elimination results in great changes in the simulated values. ${ }^{(11)}$ In this work, we considered a reaction step as important, if its contribution to the formation rate of any

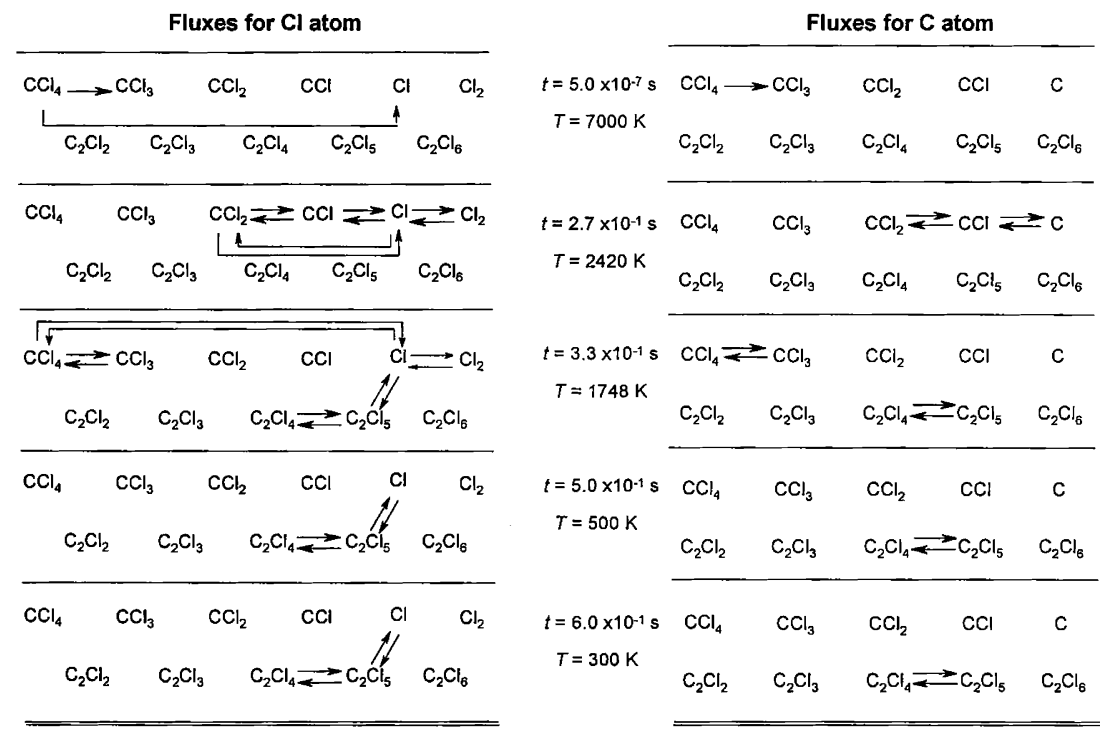

Fig. 5. The net fluxes of $\mathrm{Cl}-$ and $\mathrm{C}$-atoms. 
species is larger than 5\% compared to the most effective reaction step. Reaction steps being important at reaction times selected for the investigations in this work are denoted by $\mathbf{x}$ in Table III. Numbering of reaction times corresponds to those listed in Table II. At temperatures close to $7000 \mathrm{~K}$, the dominating ones steps are reactions 1, 3, 5, and 7. At lower

Table III. Importance of the Reaction Steps

\begin{tabular}{|c|c|c|c|c|c|c|c|c|c|c|c|c|c|}
\hline Reactions & 1 & 2 & 3 & 4 & 5 & 6 & 7 & 8 & 9 & 10 & 11 & 12 & 13 \\
\hline $\mathrm{CCl}_{4}+\mathrm{Ar} \rightarrow \mathrm{CCl}_{3}+\mathrm{Cl}+\mathrm{Ar}$ & $\mathrm{X}$ & $\mathrm{X}$ & $\mathrm{X}$ & $\mathrm{X}$ & $\mathrm{X}$ & $\mathrm{X}$ & $\mathrm{X}$ & $\mathrm{X}$ & $\mathrm{X}$ & & & & \\
\hline $\mathrm{CCl}_{3}+\mathrm{Cl}+\mathrm{Ar} \rightarrow \mathrm{CCl}_{4}+\mathrm{Ar}$ & & & $\mathrm{X}$ & $\mathrm{X}$ & $\mathrm{X}$ & $\mathrm{X}$ & $\mathrm{X}$ & $\mathrm{X}$ & $\mathrm{X}$ & & & & \\
\hline $\mathrm{CCl}_{3}+\mathrm{Ar} \rightarrow \mathrm{CCl}_{2}+\mathrm{Cl}+\mathrm{Ar}$ & $\mathrm{X}$ & $\mathrm{X}$ & $\mathrm{X}$ & $\mathrm{X}$ & $\mathrm{X}$ & $\mathrm{X}$ & $\mathrm{X}$ & $\mathrm{X}$ & $\mathrm{X}$ & & & & \\
\hline $\mathrm{CCl}_{2}+\mathrm{Cl}+\mathrm{Ar} \rightarrow \mathrm{CCl}_{3}+\mathrm{Ar}$ & & & $\mathrm{X}$ & $\mathrm{X}$ & $\mathrm{X}$ & $X$ & $\mathrm{X}$ & $\mathrm{X}$ & $\mathrm{X}$ & $\mathrm{X}$ & $\mathrm{X}$ & & \\
\hline $\mathrm{CCl}_{2}+\mathrm{Ar} \rightarrow \mathrm{CCl}+\mathrm{Cl}+\mathrm{Ar}$ & $\mathrm{X}$ & $\mathrm{X}$ & $\mathrm{X}$ & $\mathrm{X}$ & $\mathrm{X}$ & $\mathrm{X}$ & $\mathrm{X}$ & $\mathrm{X}$ & $\mathrm{X}$ & $\mathrm{X}$ & $\mathrm{X}$ & $X$ & $\mathrm{X}$ \\
\hline $\mathrm{CCl}+\mathrm{Cl}+\mathrm{Ar} \rightarrow \mathrm{CCl}_{2}+\mathrm{Ar}$ & & & $\mathrm{X}$ & $\mathrm{X}$ & $\mathrm{X}$ & $\mathrm{X}$ & $\mathrm{X}$ & $\mathrm{X}$ & $\mathrm{X}$ & $\mathrm{X}$ & $\mathrm{X}$ & $\mathrm{X}$ & $\mathrm{X}$ \\
\hline $\mathrm{CCl}+\mathrm{Ar} \rightarrow \mathrm{C}+\mathrm{Cl}+\mathrm{Ar}$ & $\mathrm{X}$ & $\mathrm{X}$ & $\mathrm{X}$ & $\mathrm{X}$ & $\mathrm{X}$ & $\mathrm{X}$ & $\mathrm{X}$ & $\mathrm{X}$ & $\mathrm{X}$ & & & & \\
\hline $\mathrm{C}+\mathrm{Cl}+\mathrm{Ar} \rightarrow \mathrm{CCl}+\mathrm{Ar}$ & & & $\mathrm{X}$ & $\mathrm{X}$ & $\mathrm{X}$ & $\mathrm{X}$ & $\mathrm{X}$ & $\mathrm{X}$ & $\mathrm{X}$ & $X$ & $\mathrm{X}$ & X & $\mathrm{X}$ \\
\hline $\mathrm{CCl}_{2}+\mathrm{C} \rightarrow 2 \mathrm{CCl}$ & & & & & & & & & & & & & \\
\hline $2 \mathrm{CCl} \rightarrow \mathrm{CCl}_{2}+\mathrm{C}$ & & & & & & & & & & & & & \\
\hline $\mathrm{CCl}_{4}+\mathrm{Cl} \rightarrow \mathrm{CCl}_{3}+2 \mathrm{Cl}$ & & & & & & & & & & $\mathrm{X}$ & $\mathrm{X}$ & & \\
\hline $\mathrm{CCl}_{3}+2 \mathrm{Cl} \rightarrow \mathrm{CCl}_{4}+\mathrm{Cl}$ & & & & & & & & & & $\mathrm{X}$ & $\mathrm{X}$ & $\mathrm{X}$ & X \\
\hline $\mathrm{CCl}_{4}+\mathrm{C} \rightarrow \mathrm{CCl}_{3}+\mathrm{CCl}$ & & & & & & & & $\mathrm{X}$ & $\mathrm{X}$ & & & & \\
\hline $\mathrm{CCl}_{3}+\mathrm{CCl} \rightarrow \mathrm{CCl}_{4}+\mathrm{C}$ & & & & & & & & $\mathrm{X}$ & $\mathrm{X}$ & & & & \\
\hline $2 \mathrm{CCl}_{3} \rightarrow \mathrm{C}_{2} \mathrm{Cl}_{6}$ & $\mathrm{X}$ & $\mathrm{X}$ & $\mathrm{X}$ & $\mathrm{X}$ & $\mathrm{X}$ & $\mathrm{X}$ & $\mathrm{X}$ & $\mathrm{X}$ & $\mathrm{X}$ & & & & \\
\hline $\mathrm{C}_{2} \mathrm{Cl}_{6} \rightarrow 2 \mathrm{CCl}_{3}$ & $\mathrm{X}$ & $\mathrm{X}$ & $\mathrm{X}$ & $\mathrm{X}$ & $\mathrm{X}$ & $X$ & $\mathrm{X}$ & & & & & & \\
\hline $\mathrm{C}_{2} \mathrm{Cl}_{6}+\mathrm{CCl}_{3} \rightarrow \mathrm{CCl}_{4}+\mathrm{C}_{2} \mathrm{Cl}_{5}$ & & & & & & & & & & & & & \\
\hline $\mathrm{C}_{2} \mathrm{Cl}_{5}+\mathrm{CCl}_{4} \rightarrow \mathrm{CCl}_{3}+\mathrm{C}_{2} \mathrm{Cl}_{6}$ & & & & & & & & & & & $\mathrm{X}$ & $\mathrm{X}$ & $\mathrm{X}$ \\
\hline $\mathrm{C}_{2} \mathrm{Cl}_{5}+\mathrm{Cl}_{2} \rightarrow \mathrm{C}_{2} \mathrm{Cl}_{6}+\mathrm{Cl}$ & & & & & & & & & $\mathrm{X}$ & $\mathrm{X}$ & $\mathrm{X}$ & $\mathrm{X}$ & $\mathrm{X}$ \\
\hline $\mathrm{C}_{2} \mathrm{Cl}_{6}+\mathrm{Cl} \rightarrow \mathrm{C}_{2} \mathrm{Cl}_{5}+\mathrm{Cl}_{2}$ & $\mathrm{X}$ & $\mathrm{X}$ & $\mathrm{X}$ & $\mathrm{X}$ & $\mathrm{X}$ & $\mathrm{X}$ & $\mathrm{X}$ & $\mathrm{X}$ & & & & & \\
\hline $\mathrm{C}_{2} \mathrm{Cl}_{5} \rightarrow \mathrm{C}_{2} \mathrm{Cl}_{4}+\mathrm{Cl}$ & $\mathrm{X}$ & $\mathrm{X}$ & $\mathrm{X}$ & $\mathrm{X}$ & $\mathrm{X}$ & $\mathrm{X}$ & $\mathrm{X}$ & $\mathrm{X}$ & $\mathrm{X}$ & $\mathrm{X}$ & $\mathrm{X}$ & $\mathrm{X}$ & $\mathrm{X}$ \\
\hline $\mathrm{C}_{2} \mathrm{Cl}_{4}+\mathrm{Cl} \rightarrow \mathrm{C}_{2} \mathrm{Cl}_{5}$ & & & $\mathrm{X}$ & $\mathrm{X}$ & $\mathrm{X}$ & $\mathrm{X}$ & $\mathrm{X}$ & $\mathrm{X}$ & $\mathrm{X}$ & $\mathrm{X}$ & $\mathrm{X}$ & $\mathrm{X}$ & $\mathrm{X}$ \\
\hline $\mathrm{C}_{2} \mathrm{Cl}_{5}+\mathrm{Cl} \rightarrow \mathrm{C}_{2} \mathrm{Cl}_{4}+\mathrm{Cl}_{2}$ & & & & & & & & & & & $\mathrm{X}$ & $\mathrm{X}$ & $\mathrm{X}$ \\
\hline $\mathrm{C}_{2} \mathrm{Cl}_{4}+\mathrm{Cl}_{2} \rightarrow \mathrm{C}_{2} \mathrm{Cl}_{5}+\mathrm{Cl}$ & & & & & & & & & & & & & \\
\hline $2 \mathrm{Cl}+\mathrm{Ar} \rightarrow \mathrm{Cl}_{2}+\mathrm{Ar}$ & $\mathrm{X}$ & $\mathrm{X}$ & $\mathrm{X}$ & $\mathrm{X}$ & $\mathrm{X}$ & $\mathrm{X}$ & $\mathrm{X}$ & $\mathrm{X}$ & $\mathrm{X}$ & $\mathrm{X}$ & & & \\
\hline $\mathrm{Cl}_{2}+\mathrm{Ar} \rightarrow 2 \mathrm{Cl}+\mathrm{Ar}$ & $\mathrm{X}$ & $\mathrm{X}$ & $\mathrm{X}$ & $\mathrm{X}$ & $\mathrm{X}$ & $\mathrm{X}$ & $\mathrm{X}$ & $\mathrm{X}$ & $\mathrm{X}$ & & & & \\
\hline $2 \mathrm{CCl}+\mathrm{Ar} \rightarrow \mathrm{C}_{2} \mathrm{Cl}_{2}+\mathrm{Ar}$ & & & $\mathrm{X}$ & $\mathrm{X}$ & & & & & & & & & \\
\hline $\mathrm{C}_{2} \mathrm{Cl}_{2}+\mathrm{Ar} \rightarrow 2 \mathrm{CCl}+\mathrm{Ar}$ & & & $X$ & & & & & & & & & & \\
\hline $2 \mathrm{CCl}_{2}+\mathrm{Ar} \rightarrow \mathrm{C}_{2} \mathrm{Cl}_{4}+\mathrm{Ar}$ & $\mathrm{X}$ & $\mathrm{X}$ & $\mathrm{X}$ & $\mathrm{X}$ & $\mathrm{X}$ & $X$ & $\mathrm{X}$ & $\mathrm{X}$ & $\mathrm{X}$ & $\mathrm{X}$ & $\mathrm{X}$ & $\mathrm{X}$ & $\mathrm{X}$ \\
\hline $\mathrm{C}_{2} \mathrm{Cl}_{4}+\mathrm{Ar} \rightarrow 2 \mathrm{CCl}_{2}+\mathrm{Ar}$ & & & & & & & & & & & & & \\
\hline $\mathrm{C}_{2} \mathrm{Cl}_{2}+\mathrm{Cl}+\mathrm{Ar} \rightarrow \mathrm{C}_{2} \mathrm{Cl}_{3}+\mathrm{Ar}$ & & & $\mathrm{X}$ & $X$ & $\mathrm{X}$ & $\mathrm{X}$ & $\mathrm{X}$ & $\mathrm{X}$ & $\mathrm{X}$ & $\mathrm{X}$ & $\mathrm{X}$ & $\mathrm{X}$ & $\mathrm{X}$ \\
\hline $\mathrm{C}_{2} \mathrm{Cl}_{3}+\mathrm{Ar} \rightarrow \mathrm{C}_{2} \mathrm{Cl}_{2}+\mathrm{Cl}+\mathrm{Ar}$ & $\mathrm{X}$ & $\mathrm{X}$ & $\mathrm{X}$ & $\mathrm{X}$ & $\mathrm{X}$ & $\mathrm{X}$ & $\mathrm{X}$ & $\mathrm{X}$ & $\mathrm{X}$ & & & & \\
\hline $\mathrm{C}_{2} \mathrm{Cl}_{3}+\mathrm{Cl} \rightarrow \mathrm{C}_{2} \mathrm{Cl}_{4}$ & & & & & $\mathrm{X}$ & $\mathrm{X}$ & $\mathrm{X}$ & $\mathrm{X}$ & $\mathrm{X}$ & $\mathrm{X}$ & $\mathrm{X}$ & $\mathrm{X}$ & $\mathrm{X}$ \\
\hline $\mathrm{C}_{2} \mathrm{Cl}_{4} \rightarrow \mathrm{C}_{2} \mathrm{Cl}_{3}+\mathrm{Cl}$ & $\mathrm{X}$ & $\mathrm{X}$ & $\mathrm{X}$ & $\mathrm{X}$ & $\mathrm{X}$ & $\mathrm{X}$ & $\mathrm{X}$ & $\mathrm{X}$ & $\mathrm{X}$ & & & & \\
\hline
\end{tabular}


temperatures, the backward reactions (No. 2, 4, 6 and 8) are also important. Steps generating $\mathrm{C}$ and $\mathrm{Cl}$ slow down by decreasing the temperature further on. However, larger radicals (such as $\mathrm{CCl}, \mathrm{CCl}_{2}$, and $\mathrm{CCl}_{3}$ ) and $\mathrm{C}_{2}$-species $\left(\mathrm{C}_{2} \mathrm{Cl}_{3}\right.$ and $\left.\mathrm{C}_{2} \mathrm{Cl}_{5}\right)$ are generated faster at lower temperatures as it can be seen in Fig. 2c-e. The reaction scheme can be divided to two regimes, separated approximately by time point of $4 \times 10^{-2} \mathrm{~s}$ corresponding to the reaction temperature of $1400 \mathrm{~K}$. At reaction times below $4 \times 10^{-2} \mathrm{~s}$ reactions of $\mathrm{C}_{1}$-species are dominating, while after it reactions of $\mathrm{C}_{2}$-species are important. Recombination of $\mathrm{CCl}_{4}$ becomes significant in the second regime. Five reactions (reactions No. 9, 10, 17, 24, and 34) can be eliminated from the mechanism, because they are not important at any reaction time. Simulations were repeated using the reduced mechanism. Identical results were obtained with the reduced mechanism as with the full 34-step mechanism.

\section{CONCLUSIONS}

Decomposition of $\mathrm{CCl}_{4}$ was investigated in an RF inductively coupled thermal plasma reactor in argon atmosphere. The outlet gas mixture was cooled to room temperature, and was subsequently analyzed by GC-MS. The kinetics of $\mathrm{CCl}_{4}$ decomposition at the actual experimental conditions was modeled in the temperature range from 300 to $7000 \mathrm{~K}$. The created reaction mechanism contained 34 irreversible reaction steps of 12 species. Kinetic calculations provided concentration-time profiles for each species. The total carbon tetrachloride feed was decomposed within $5 \times 10^{-5} \mathrm{~s}$. However, it was partly recombined from the decomposition products. Our calculations predicted a $70 \%$ net conversion of $\mathrm{CCl}_{4}$, which was close to the experimentally determined value of $60 \%$. The kinetic mechanism was analyzed in two ways. Analysis of the fluxes of C- and $\mathrm{Cl}$-atoms revealed the change of inter-conversion rates among species during the reaction. Importance of reaction steps was investigated by rate-of-production analysis. It revealed the significant change of the importance of reaction steps with reaction time. Only five reaction steps of the total 34 were found to be unimportant at any reaction time.

\section{ACKNOWLEDGMENTS}

The authors acknowledge the helpful discussions with István Gy. Zsély. The Hungarian Scientific Research Fund (OTKA Grant No. T043770 and No. T029734) has supported this work. 


\section{REFERENCES}

1. K. A. Föglein, P. T. Szabó, A. Dombi, and J. Szépvölgyi, Plasma Chem. Plasma Process. 23, 651 (2003).

2. P. Proulx and J. F. Bilodeau, Plasma Chem. Plasma Process. 11, 371 (1991).

3. A. E. Lutz, R. J. Kee, and J. A. Miller, SENKIN: A FORTRAN program for predicting homogeneous gas phase chemical kinetics with sensitivity analysis. SANDIA Report No. SAND87-8248, 1987.

4. R. J. Kee, F. M. Rupley, and J. A. Miller, CHEMKIN-II: A FORTRAN chemical kinetics package for the analysis of gas-phase chemical kinetics. SANDIA Report No. SAND89-8009B, 1989.

5. Burcat's Thermodynamical Database. ftp://ftp.technion.ac.il/pub/supported/aetdd/thermodynamics/; also available from; http://garfield.chem.elte.hu/Burcat/burcat.html, last access date October 2003

6. NIST Chemical Kinetics Database. http://kinetics.nist.gov/index.php, last access date October 2003

7. T. Turányi, MECHMOD: program for the modification of gas kinetic mechanisms. http://garfield.chem.elte.hu/Combustion/mechmod.htm, last access date October 2003

8. I. Orlandini and U. Riedel, Combust. Theor. Model. 5, 447 (2001).

9. T. Turányi, KINALC: program for the analysis of gas kinetic mechanisms. http://garfield.chem.elte.hu/Combustion/kinalc.htm, last access date October 2003

10. J. Revel, J. C. Boettner, M. Cathonnet, and J. S. Bachman, J. Chim. Phys. 91, 365-382 (1994).

11. T. Turányi, New J. Chem. 14, 795 (1990).

12. J. V. Michael, and K. P. Lim, J. Phys. Chem. 97, 1914 (1993).

13. A. P. Modica, and S. J. Sillers, J. Chem. Phys. 48, 3283 (1968).

14. S. S. Kumaran, M. C. Su, K. P. Lim, J. V. Michael, S. J. Klippenstein, J. DiFelice, P. S. Mudipalli, J. H. Kiefer, D. A. Dixon, and K. A. Peterson, J. Phys. Chem. A., 101, 8653 (1997).

15. A. J. Dean and R. K. Hanson, Int. J. Chem. Kinet. 24, 517 (1992).

16. G. Huybrechts, M. Narmon, and B. Van Mele, Int. J. Chem. Kinet. 28, 27 (1996).

17. N. Haider and D. Husain, Combust. Flame 93, 327 (1993).

18. M. Pesa, M. J. Pilling, S. H. Robertson, and D. M. Wardlaw, J. Phys. Chem. A 102, 8526 (1998).

19. G. Huybrechts, M. Narmon, and B. Van Mele, Int. J. Chem. Kinet. 28, 27 (1996).

20. T. T. Song and T. M. Su, J. Phys. Chem. 100, 13554 (1996). 